coronary events with lovastatin in men and women with average cholesterol levels: results of AFCAPS/TexCAPS. JAMA 1998;279:1615-22.

7 Shepherd J, Cobbe SM, Ford I, Isles CG, Lorimer AR, MacFarlane PW, et al. Prevention of coronary heart disease with pravastatin in men with hypercholesterolemia. $N$ Engl J Med 1995;333:1301-7.

8 Hansson L, Zanchetti A, Carruthers SG, Dahlof B, Elmfeldt D, Julius S, et al. Effects of intensive blood-pressure lowering and low-dose aspirin in patients with hypertension: principal results of the hypertension optimal treatment (HOT) randomised trial. Lancet 1998;351:1755-62.

9 MacMahon SW, Cutler JA, Neaton JD, Furberg CD, Cohen JD, Kuller LH, et al. Relationship of blood pressure to coronary and stroke morbidity and mortality in clinical trials and epidemiological studies. J Hypertens 1986;4(suppl):S14-7.

10 Prescott E, Hippe M, Schnohr P, Hein HO, Vestbo J. Smoking and the risk of myocardial infarction in women and men: longitudinal population study. BMJ 1998;316:1043-47

11 UK Prospective Diabetes Study Group. Tight blood pressure control and risk of macrovascular and microvascular complications in type 2 diabetes (UKPDS 38). BMJ 1998;317:703-13.

12 UK Prospective Diabetes Study (UKPDS) Group. Intensive blood-glucose control with sulphonylureas or insulin compared with conventional treatment and risk of complications in patients with type 2 diabetes. Lancet 1998;352:837-85.

13 Scandinavian Simvastatin Survival Study Group. Randomised trial of cholesterol lowering in 4444 patients with coronary heart disease: the Scandinavian Simvastatin Survival Study (4S). Lancet 1994;344:1383-89.

14 Medical Research Council general practice research framework. Thrombosis prevention trial: randomised trial of low intensity oral anti-coagulation with warfarin and low-dose aspirin in the primary preanti-coagulation with warfarin and low-dose aspirin in the primary pre-
vention of ischaemic heart disease in men at increased risk. Lancet vention of ischae

15 Mehta RH, Eagle KA. Secondary prevention in acute myocardial infarction. $B M J$ 1998;316:838-42.

16 Anderson KM, Odell PM, Wilson PWF, Kannel WE. Cardiovascular disease risk profiles. Am Heart J 1991;121:293-8.

17 Second Joint Task Force of European and Other Societies on Coronary Prevention. Prevention of coronary heart disease in clinical practice. Eur Heart J 1998;19:1434-503.

18 National Cholesterol Education Program. Second report of the expert panel on detection, evaluation, and treatment of high blood cholesterol in adults (adult treatment panel II). Circulation 1994;89:1329-445.

19 National Health Committee. Guidelines for the management of mildly raised blood pressure in New Zealand. Wellington: Ministry of Health, 1998. www.nzgg.org.nz/library/gl_complete/bloodpressure/ index.cfm\#contents (accessed 5 Sept 2001).

20 Department of Health. National service framework for coronary heart disease. London: HMSO, 2000

21 Wallis EJ, Ramsay LE, Ul Haq I, Ghahramani P, Jackson PR, Rowland-Yeo $\mathrm{K}$, et al. Coronary and cardiovascular risk estimation for primary prevention: population validation of a new Sheffield table. BMJ 2000;320:671-6.

22 Isles CG, Ritchie LD, Murchie P, Norrie J. Risk assessment in primary prevention of coronary heart disease: randomised comparison of three scoring methods. BMJ 2000;320:690-1.

23 Peters TJ, Montgomery AA, Fahey T. How accurately do primary health care professionals use cardiovascular risk tables in the management of hypertension? BrJ Gen Pract 1999;49:987-8.

24 Grover SA, Lowensteyn I, Esrey KL, Steinert Y, Joseph L, Abrahamowicz M. Do doctors accurately assess coronary risk in their patients? Preliminary results of the coronary health assessment study. BMJ 1995;310:975-8.

25 Montgomery AA, Fahey T, Mackintosh C, Sharp DJ, Peters TJ. Estimation of cardiovascular risk in hypertensive patients in primary care. Br J Gen Pract 2000;50:127-8

26 Ramsay LE, Haq IU, Jackson PR, Yeo WW, Pickin DM, Payne JN. Targeting lipid-lowering drug therapy for primary prevention of coronary disease: an updated Sheffield table. Lancet 1996;348:387-8.

27 Wood D. European and American recommendations for coronary heart disease prevention. Eur Heart J 1998;19 (Suppl A):A12-9.

28 British Cardiac Society, British Hyperlipidaemia Association, British Hypertension Society, endorsed by the British Diabetic Association. Joint British recommendations on prevention of coronary heart disease in clinical practice. Heart 1998;80(suppl 2):1-29. http://heart.bmjjournals. $\mathrm{com} / \mathrm{cgi} /$ content/full/80/suppl_2/S1 (accessed 21 Dec 2001).

29 Erens R, Primatesta P. Health survey for England 1998. London: Stationery Office, 1999:1-368.

30 Landis JR, Koch GG. The measurement of observer agreement for categorical data. Biometrics 1977;33:159-74.

(Accepted 15 October 2001)

\title{
Experiences and career intentions of general practice registrars in Thames deaneries: postal survey
}

Isobel Bowler, Neil Jackson

22 Marriott Road, London N4 3QL

Isobel Bowler independent health service researcher

London

Department of

Postgraduate

Medical and Dental

Education, London

WC1N 1DZ

Neil Jackson

dean of postgraduate

general practice

education

Correspondence to:

I Bowler

isobel@gower.

u-net.com

BMJ 2002;324:464-5
The national plan for the NHS in Britain has promised an additional 2000 general practitioners and 550 training places for general practice registrars by $2004 .{ }^{1}$ A study of the experiences and career intentions of general practice registrars was commissioned by the four deans of postgraduate general practice education responsible for south east England. These deaneries included a third of all registrars in general practice training in England. ${ }^{2}$

\section{Methods and results}

A postal questionnaire was developed, piloted, and sent to all 470 general practice registrars in the Thames deaneries in April 2000. Altogether 373 (79\%) completed questionnaires were returned, 92\% $(330 / 358)$ by registrars in their final year of training. The proportion of female respondents $(60 \%, 218 /$ 365) was similar to the national average ${ }^{2}$; the participants' median age was 30.0 years (mean 31.5 years). Most had trained in UK medical schools, but 29\% (108/373) had qualified overseas (table). Doctors qualified overseas were older than UK graduates. Almost two thirds had chosen general practice after becoming a doctor, a median of three years after qualification.

Most registrars were satisfied with their training. Fifty eight per cent $(213 / 366)$ would prefer the general practice component of training to be extended by six months, to 18 months. Seventy four per cent (272/369) would be interested in a salaried post combining clinical work with further training and development for 12 months, and 70\% (257) would be interested in a programme of higher professional education for up to 12 months after completing training.

Altogether 94\% (349/370) intended to work in general practice in the United Kingdom at some stage in their career, $1 \%$ (4) did not intend to do so, and 4\% (17) were undecided. Four per cent $(2 / 45)$ of doctors who had qualified in the European Union did not intend to work in the United Kingdom and 22\% who had qualified in the United Kingdom (10) were undecided $\left(\mathrm{P}<0.0001, \chi^{2}\right.$ test). Graduates from medical schools outside the European Union had similar intentions to graduates from the United Kingdom.

Overall 74\% (275/370) intended to take a general practice job immediately after training, but only $26 \%$ (96) a principalship. A significantly higher proportion of men than women intended to go straight into a principalship $\quad(37 \% \quad(54 / 147) \quad v \quad 18 \% \quad(39 / 218)$; $\mathrm{P}<0.001, \chi^{2}$ test). Overall, $81 \%(301 / 373)$ intended to be a principal at some stage $(14 \%$ (53) were undecided). Overall, 52\% (194/370) anticipated becoming a principal within 12 months and a further 24\% (89) within 24 months of finishing training. 
Characteristics of general practice registrars participating in the survey. Where the difference by sex is significant, the results are given. Values are percentages (numbers) unless otherwise specified

\begin{tabular}{|c|c|}
\hline & Value \\
\hline \multicolumn{2}{|l|}{ Sex $(n=365)$ : } \\
\hline Men & 40 (147) \\
\hline Women & $60(218)$ \\
\hline Median (range) age $(\mathrm{n}=362)$ : & $30.0(95 \% \mathrm{Cl} 24$ to 59$)$ \\
\hline \multicolumn{2}{|l|}{ By place of qualificationt: } \\
\hline UK medical school $(\mathrm{n}=259)$ & $29.0(24-50)$ \\
\hline Non-UK medical school $(n=103)$ & $35.0(25-59)$ \\
\hline EU medical school $(n=44)$ & $33.50(25-50)$ \\
\hline Non-EU medical school $(n=59)$ & $35.0(28-59)$ \\
\hline \multicolumn{2}{|l|}{ Medical school $(n=373)$ : } \\
\hline In UK & $71(265)$ \\
\hline Elsewhere in EU & $12(45)$ \\
\hline Elsewhere in world & $17(63)$ \\
\hline \multicolumn{2}{|l|}{ Medical school attendance by sex $(n=365):{ }^{*}$} \\
\hline Men (non-UK school) $(n=147)$ & $37(55)$ \\
\hline Women (non-UK school) (n=218) & $23(50)$ \\
\hline \multicolumn{2}{|c|}{ Timing of decision to become general practitioner $(n=373)$ : } \\
\hline Before medical school & $7(26)$ \\
\hline At medical school & $17(65)$ \\
\hline During preregistration year & $14(52)$ \\
\hline After becoming doctor & $62(230)$ \\
\hline Median (range) number of years $(\mathrm{n}=229) \ddagger$ & $3.0(0-23)$ \\
\hline \multicolumn{2}{|l|}{ Type of general practitioner training $(\mathrm{n}=372)$ : } \\
\hline Three year vocational scheme & 46 (171) \\
\hline $\begin{array}{l}\text { Registrar year after self organised hospital } \\
\text { training }\end{array}$ & 54 (201) \\
\hline
\end{tabular}

training

Full or part time training $(\mathrm{n}=372)$ :

\begin{tabular}{|c|c|}
\hline Part time & $8(28)$ \\
\hline Men $(n=147)$ & $1(2)$ \\
\hline Women $(n=218)$ & $12(25)$ \\
\hline \multicolumn{2}{|c|}{ Satisfaction with general practitioner training $(n=364)$ : } \\
\hline Satisfied or very satisfied & $77(281)$ \\
\hline Mixed & $17(61)$ \\
\hline Dissatisfied or very dissatisfied & $6(22)$ \\
\hline \multicolumn{2}{|c|}{ Life partner's career affects where registrar can work $(n=295):{ }^{*}$} \\
\hline Women $(n=170)$ & $79(134)$ \\
\hline Men $(n=113)$ & $53(60)$ \\
\hline \multicolumn{2}{|l|}{ Marital status $(n=373)$ : } \\
\hline Has spouse or partner & $79(295)$ \\
\hline Spouse or partner is doctor & $29(107)$ \\
\hline Has children under $18(n=371)$ : & $33(123)$ \\
\hline Men $(n=147)^{\star \star \star}$ & $40(58)$ \\
\hline Women $(n=218)$ & $29(63)$ \\
\hline
\end{tabular}

tDifferences are significant between UK and non-UK graduates $(P<0.0001$ $t$ test) and between EU and other overseas qualified doctors ( $\mathrm{P}=0.006, t$ test). fMean (SD) 4.7 (4.34). ${ }^{*} P=0.003, \chi^{2}$ test. ${ }^{* *} P<0.0001, \chi^{2}$ test. ${ }_{* \star \star} P<0.036, \chi^{2}$ test.

Of those intending to be principals, $48 \%(143 / 301)$ planned to work full time. Thirty per cent $(51 / 171)$ of women and $75 \%(91 / 122)$ of men planned to work full time $\left(\mathrm{P}<0.0005, \chi^{2}\right.$ test). Overall, almost half $(49 \%, 179 /$ $365)$ planned to work in general practice in the health authority in which they trained, $38 \%$ (138) as a principal.

\section{Comment}

Our study shows that the government's national plan may understimate the numbers of new doctors needed. Another study has estimated that 150 new entrants to general practice are required to replace 100 retiring principals, but this is a minimum figure. ${ }^{3}$ If the government's ambitious target of 2000 more general practitioners is to be met, then the 550 promised new training posts will not be enough. Qualified doctors currently in practice should be retained and encouraged to participate more in the workforce.

More than $10 \%$ of doctors training for general practice had attended medical school in other EU countries, and this group showed less commitment to working in general practice in the United Kingdom. Only half the registrars intended to stay in the health authority where they trained. Many expressed an interest in working part time, especially women registrars, who now make up more than half of doctors training for general practice.

NJ, Patrick Pietroni, Abdol Tavabie, and Ri Hornung (the four deans of postgraduate general practice for the former North and South Thames deaneries) had the idea for the survey and commissioned the work. They commented on the draft questionnaire, coordinated the mailout to the registrars in their deaneries, and commented on earlier drafts of this paper. NJ also arranged the piloting of the questionnaire and commented on the final draft of the paper. IB reviewed the literature, designed the questionnaire, analysed the data, and wrote this paper. Jackie Bradford entered the data. IB is the guarantor.

Funding: The work was funded by the four Thames postgraduate general practice deaneries.

Competing interests: None declared.

1 Secretary of State for Health. The NHS plan.A plan for investment. A plan for reform. London: Stationery Office, 2000.

2 NHS Executive. General and personal medical statistics England and Wales: 1 October 1999. Leeds: NHS Executive, 2000.

3 Royal College of General Practitioners. The primary care workforce. A descriptive analysis. London: RCGP, 1997.

(Accepted 27 October 2001)

\section{Christmas corrections and clarifications}

\section{Photofinish}

We unfortunately neglected to include the names of two contributors to the final page in our Christmas issue. We apologise for not attributing the piece about the Kettering hypertherm to Dr J Martin Stewart, a retired general practitioner from Oxford and Dr Rob Wilcox from Flinders Medical Centre in Adelaide, South Australia.

In grandfather's room

We were 10 years out with a date in this article by A M Clarfield (22-29 December, pp 1496-7). The article was originally published in the New York Times Sunday Magazine in 1986, not in 1996.

Christiaan Barnard: his first transplants and their impact on concepts of death

We have received several communications about a photograph that appeared in this article by Raymond Hoffenberg (22-29 December, pp 1478-80). We published what we thought was a 1967 photograph of Christiaan Barnard explaining heart transplantation. However, some readers have told us that the photograph shows Marius Barnard, Christiaan's brother. Hoffenberg himself was at first sure that it was Christiaan but now thinks it may indeed be Marius. The picture agency that supplied the picture has no information other than that it is Christiaan.

Income, health, and the National Lottery We inadvertently repeated a sentence in this editorial by Anthony Rodgers (22-29 December, pp 1438-9). The first part of the final sentence should have been omitted. Also, the penultimate sentence of the second paragraph should include the words "education" (after "employment") and "even" (before "entrepreneurship"). 